\title{
Narrowband ultraviolet B phototherapy and serum folic acid level
}

\author{
Viroj Wiwanitkit
}

Received: 24 February 2011 / Accepted: 7 July 2011 /Published online: 23 July 2011

(C) Springer-Verlag London Ltd 2011

\section{Dear Sirs,}

I read with great interest the recent publication on "narrowband ultraviolet B phototherapy" [1]. The effect of narrowband ultraviolet B phototherapy on serum folic acid levels still remains inconclusive [1-3]. The effect has been determined in some studies, whereas findings are discordant in others [3]. There are many points that remain disputable. Quality control in determining serum folic acid levels should be mentioned first [4]. Second, there are many factors that can affect folic acid levels. Nutritional status [5] and some congenital blood disorders (such as thalassemia) $[6,7]$ serve as good examples. Some practices, such as vegetarianism and alcohol consumption, can also result in decreased serum folate levels [5]. Focusing on thalassemia, a trend is observed to low serum folate levels after exposure to stress [7]. These factors have to be considered when results are interpreted.

\section{References}

1. El-Saie LT, Rabie AR, Kamel MI, Seddeik AK (2011) Elsaie ML. Effect of narrowband ultraviolet B phototherapy on serum folic acid levels in patients with psoriasis, Lasers Med Sci [Epub ahead of print]

2. Murase JE, Koo JY, Berger TG (2010) Narrowband ultraviolet B phototherapy influences serum folate levels in patients with vitiligo. J Am Acad Dermatol 62(4):710-711

3. Rose RF, Batchelor RJ, Turner D, Goulden V (2009) Narrowband ultraviolet B phototherapy does not influence serum and red cell folate levels in patients with psoriasis. J Am Acad Dermatol 61(2):259-262

4. van den Berg H, Finglas PM, Bates C (1994) FLAIR intercomparisons on serum and red cell folate. Int J Vitam Nutr Res 64(4):288-293

5. Olusi SO, Jessop WJ (1977) Assessment of nutritional status. Afr J Med Med Sci 6(3):149-156

6. Tso SC (1976) Significance of subnormal red-cell folate in thalassaemia. J Clin Pathol 29(2):140-143

7. Ozdem S, Kupesiz A, Yesilipek A (2008) Plasma homocysteine levels in patients with beta-thalassaemia major. Scand J Clin Lab Invest 68(2):134-139

\footnotetext{
V. Wiwanitkit $(\bowtie)$

Wiwanitkit House,

Bangkhae, Bangkok, Thailand 10160

e-mail: wviroj@yahoo.com

V. Wiwanitkit

Hainan Medical University,

Hainan, China
} 